\title{
Opposite Regulation of Human Versus Mouse Apolipoprotein A-I by Fibrates in Human Apolipoprotein A-I Transgenic Mice
}

\author{
Laurence Berthou, ${ }^{\star}$ Nicolas Duverger, ${ }^{\star}$ Florence Emmanuel, ${ }^{\star}$ Sophie Langouët, ${ }^{\S}$ Johan Auwerx, ${ }^{\ddagger}$ André Guillouzo, ${ }^{\S}$ \\ Jean-Charles Fruchart, ${ }^{\ddagger}$ Edward Rubin,$\|$ Patrice Denèfle, ${ }^{*}$ Bart Staels, ${ }^{\ddagger}$ and Didier Branellec ${ }^{\star}$ \\ *Department of Biotechnology C.R.V.A. Rhône-Poulenc Rorer Gencell, Vitry-sur-Seine 94403; ${ }^{\ddagger}$ U.325 INSERM, Département \\ d'Athérosclérose, Institut Pasteur de Lille, 59019 Lille; ${ }^{\S}$ U.49 INSERM, Hopital Pontchaillou Rennes, Rennes 35033, France; and \\ "Lawrence Berkeley Laboratory, University of California at Berkeley, Berkeley, California 94720
}

\begin{abstract}
The regulation of liver apolipoprotein (apo) A-I gene expression by fibrates was studied in human apo A-I transgenic mice containing a human genomic DNA fragment driving apo A-I expression in liver. Treatment with fenofibrate $(0.5 \% \mathrm{wt} / \mathrm{wt})$ for $7 \mathrm{~d}$ increased plasma human apo A-I levels up to $750 \%$ and HDL-cholesterol levels up to $200 \%$ with a shift to larger particles. The increase in human apo A-I plasma levels was time and dose dependent and was already evident after $3 \mathrm{~d}$ at the highest dose $(0.5 \% \mathrm{wt} / \mathrm{wt})$ of fenofibrate. In contrast, plasma mouse apo A-I concentration was decreased after fenofibrate in nontransgenic mice. The increase in plasma human apo A-I levels after fenofibrate treatment was associated with a $97 \%$ increase in hepatic human apo A-I mRNA, whereas mouse apo A-I mRNA levels decreased to $51 \%$. In nontransgenic mice, a similar down-regulation of hepatic apo A-I mRNA levels was observed. Nuclear run-on experiments demonstrated that the increase in human apo A-I and the decrease in mouse apo A-I gene expression after fenofibrate occurred at the transcriptional level. Since part of the effects of fibrates are mediated through the nuclear receptor PPAR (peroxisome proliferator-activated receptor), the expression of the acyl CoA oxidase (ACO) gene was measured as a control of PPAR activation. Both in transgenic and nontransgenic mice, fenofibrate induced ACO mRNA levels up to sixfold. When transgenic mice were treated with gemfibrozil $(0.5 \%$ wt/wt) plasma human apo A-I and HDL-cholesterol levels increased 32 and $73 \%$, respectively, above control levels. The weaker effect of this compound on human apo A-I and HDL-cholesterol levels correlated with a less pronounced impact on ACO mRNA levels (a threefold increase) suggesting that the level of induction of human apo A-I gene is related to the PPAR activating potency of the fibrate used. Treatment of human primary hepatocytes with fenofibric acid $(500 \mu \mathrm{M})$ provoked an 83 and $50 \%$ increase in apo A-I secretion and mRNA levels, respectively, supporting that a direct action of fibrates on liver human apo A-I production leads to the observed increase in plasma apo A-I and HDL-
\end{abstract}

Address correspondence to Dr. Bart Staels, INSERM U.325, Institut Pasteur, 1 rue du Prof. Calmette, 59019 Lille Cédex, France. Phone: 33-20-87-73-88; FAX: 33-20-87-73-60.

Received for publication 26 July 1995 and accepted in revised form 6 March 1996.

J. Clin. Invest.

(C) The American Society for Clinical Investigation, Inc.

0021-9738/96/06/2408/09 \$2.00

Volume 97, Number 11, June 1996, 2408-2416 cholesterol. (J. Clin. Invest. 1996. 97:2408-2416.) Key words: gene regulation • atherosclerosis • HDL-cholesterol • hypolipidemic drugs $\bullet$ peroxisome proliferation

\section{Introduction}

Numerous epidemiological data have demonstrated that apolipoprotein A-I, the major protein component of high density lipoproteins (HDLs), is linked to a low risk for development of coronary artery disease (1-3). Furthermore, increased production of human apo A-I by the liver in transgenic mice has been shown to confer protection against early atherogenesis (4).

Apolipoprotein gene expression can be modulated by different effectors such as fatty acids, hormones, and hypolipidemic drugs. Widely used in the treatment of hyperlipidemia $(5,6)$, fibrates decrease plasma cholesterol and triglyceride concentrations by accelerating VLDL catabolism via a combination of lipoprotein lipase activation and apo C-III reduction and by decreasing hepatic VLDL secretion (7-10). Fibric acid derivatives are further known as peroxisome proliferators in rodents, but not in humans $(11,12)$. These drugs primarily increase the transcription of many genes encoding peroxisomal proteins such as the enzymes responsible for the $\beta$-oxidation of the long-chain fatty acids (13-17). In addition, chronic exposure of rodents to fibrates can lead to hepatomegaly and hepatocarcinogenesis (18). Several lines of evidence now suggest that most activities of peroxisomal proliferators including fibrates are essentially mediated by the peroxisome proliferatoractivated receptors (PPAR) ${ }^{1}$ which belong to the nuclear hormone receptor gene superfamily (19-23).

In rodents, fibrates decrease liver apo A-I mRNA and plasma concentrations (24). Using primary cultures of adult rat hepatocytes, we recently demonstrated that the negative effect of fibrates on apo A-I gene expression results from a direct action on hepatic gene transcription (25). In humans, treatment with fibrates is consistently associated with an increase in plasma HDL-cholesterol and apo A-I concentrations (5, 26-29).

Transgenic mice overexpressing the human apo A-I gene in liver display human-like HDL particles in plasma $(30,31)$ and thus provide an excellent means to study the in vivo regulation of apo A-I expression by fibrates and its consequences on plasma HDL concentrations. We report here that fibrates induce human apo A-I and reduce mouse apo A-I gene expression in transgenic mice. Experiments on human primary hepatocytes indicate that fibrates increase apo A-I production through a direct action on cells. Moreover, nuclear run-on experiments demonstrate that the effects of fenofibrate on hu-

1. Abbreviations used in this paper: ACO, Acyl CoA oxidase; hA-I, human apo A-I; PPAR, peroxisome proliferator-activated receptor; PPRE, peroxisome proliferator response element; Tg, transgenic. 
man and mouse apo A-I gene expression occur at the transcriptional level. These results therefore suggest that the species-specific differences on apo A-I gene expression are due to different cis-acting elements in the human and mouse genes.

\section{Methods}

Animals. Two different human apo A-I transgenic mice lines were used in this study. The human apo A-I transgenic C57BL/6 mice line A2 contains 21 copies of an 11-kb human apo A-I genomic DNA fragment (31), whereas the second human apo A-I transgenic mice line (purchased from Charles River Laboratories, Wilmington, MA) contains a 2.2-kb human apo A-I genomic DNA fragment (30). Both lines contain the liver-specific enhancer of the human apo A-I gene promoter necessary to drive hepatic apo A-I expression $(30,31)$. 2-mo-old male transgenic mice and nontransgenic littermates (control) were treated with fenofibrate or gemfibrozil (Sigma Chemical Co., St. Louis, MO) mixed in mouse chow at the indicated concentrations (wt/wt). Body weights and food intake of the mice, determined every day throughout the treatment period to assess a potential toxic side effect, did not differ between treated and control animals. Blood was taken at the beginning and at the end of the experiment from the retroorbital plexus from 4-h fasted mice. Plasma was separated by centrifugation at 2,000 $\mathrm{g}$ for $15 \mathrm{~min}$ and kept at $4^{\circ} \mathrm{C}$ until analysis within $1 \mathrm{wk}$. At the end of the experiment animals were killed, and livers were removed immediately, rinsed in $0.9 \%$ saline, and frozen in liquid nitrogen before RNA extraction.

Hepatocyte isolation and culture. Human hepatocytes were obtained by a two-step collagenase perfusion of liver pieces resected for secondary hepatomas (32). Experimental procedures were approved by the National Ethics Committee (France). Cell viability was 70 $85 \%$ as estimated by the trypan blue exclusion test. Hepatocytes were plated at a density of $3 \times 10^{6} \mathrm{cells} / 3 \mathrm{ml}$ medium per $25-\mathrm{cm}^{2}$ plastic culture dish in $75 \% \mathrm{MEM} / 25 \%$ medium 199 , supplemented with $10 \%$ FCS, BSA $(1 \mathrm{mg} / \mathrm{ml})$ and bovine insulin $(10 \mu \mathrm{g} / \mathrm{ml})$. Cells were incubated at $37^{\circ} \mathrm{C}$ in a humidified atmosphere of $5 \% \mathrm{CO}_{2} / 95 \%$ air. After a 20-h attachment period, medium supplemented with dexamethasone $(0.1 \mu \mathrm{M})$ was added and renewed daily thereafter. The cells were exposed to fenofibric acid (synthesized at Rhône-Poulenc Rorer Ltd., Dagenham, UK) in $0.1 \%$ DMSO, at the first medium renewal as well as 24 and $48 \mathrm{~h}$ later. Control cultures received the same concentration of solvent ( $0.1 \%$ DMSO). $20 \mathrm{~h}$ after the last addition of drug, media were collected and stored at $-80^{\circ} \mathrm{C}$ until apolipoprotein and protein determinations were made. Cell monolayers were washed with cold PBS and solubilized in $4 \mathrm{M}$ guanidinium isothiocyanate.

Plasma lipid and lipoprotein measurements. HDL was separated from apo B-containing lipoproteins by dextran sulfate precipitation. Cholesterol was measured enzymatically using a commercially available cholesterol kit (Boehringer Mannheim Biochemicals, Indianapolis, IN) and spectrophotometrically quantified on a microplate reader (EL 311; Bio-Teck Instruments, Winooski, VT).

Lipoprotein distribution was assayed by analytical gel filtration chromatography. Plasma was applied to a prepacked Superose $6 \mathrm{HR}$ 10/30 column (Pharmacia Fine Chemicals, Uppsala, Sweden), chromatographed at a flow rate of $0.4 \mathrm{ml} \mathrm{min} \mathrm{in} 10 \mathrm{mM}$ Tris- $\mathrm{HCl}, \mathrm{pH} 7.4$, $0.15 \mathrm{M} \mathrm{NaCl}$, and $1 \mathrm{mM}$ EDTA buffer, and monitored at $280 \mathrm{~mm}$. This system allows separation of three distinct elution peaks corresponding to three major lipoprotein classes: VLDL, LDL, and HDL. Cholesterol in the eluted fractions was measured as described above. Eluted fractions were also set on a 4-20\% acrylamide gradient SDSPAGE gels and transferred to a nylon membrane. A Western blot was performed using specific human apo A-I antibodies (33).

Protein quantification. Plasma levels of mouse and human apo A-I were determined by rocket immunoelectrophoresis using specific rabbit polyclonal antibodies. There was no cross-species reactivity between mouse and human apo A-I.
Apo A-I and apo A-II protein levels in human hepatocyte culture medium were measured by a sandwich ELISA as previously described (33). Transferrin levels were measured by a competitive ELISA as described (34).

RNA analysis. RNA was isolated from liver and cultured cells by the acid guanidinium thiocyanate/phenol/chloroform method (35). Northern and dot blot of total cellular RNA were performed as described (36). For RNA hybridization, a specific human apo A-I cDNA probe was used (37). A mouse apo A-I cDNA fragment was cloned from mouse liver mRNA by reverse transcription and PCRamplification (sense primer: GAC AGC GGC AGA GAC TAT GTG TCC CAG TTT GAA; antisense primer: TGG CTT TCT CGC CAA GTG TCT TCA GGT GG). Hybridization of northern blots containing HepG2 and nontransgenic mouse liver RNA as controls for human and mouse apo A-I mRNA, respectively, revealed no cross-hybridization between human and mouse apo A-I under the hybridization and washing conditions used. An acyl CoA oxidase (ACO) cDNA probe (38) was used as a control for PPAR mediated transcriptional activation by fibrates (20), and a transferrin probe was used as a control probe for primary cultures of human hepatocytes (39). All probes were labeled by random primed labeling (rediprime kit; Amersham International, Buckinghamshire, UK). Filters were hybridized overnight to $10^{6} \mathrm{cpm} / \mathrm{ml}$ of each probe as described (36). They were washed in $0.5 \times \mathrm{SSC}$ and $0.1 \%$ SDS for $10 \mathrm{~min}$ at room temperature and twice for $30 \mathrm{~min}$ at $65^{\circ} \mathrm{C}$ and subsequently exposed to x-ray film (X-OMAT-AR; Eastman Kodak Co., Rochester, NY). Autoradiograms were analyzed by quantification scanning densitometry (GS-300 scanning densitometer; Hoefer Scientific Instruments, San Francisco, CA) as previously described (36).

Isolation of nuclei and transcriptional rate assay. Nuclei were prepared from whole liver of transgenic and nontransgenic mice untreated or treated for $5 \mathrm{~d}$ with fenofibrate $0.5 \%$ (wt/wt). Nuclei were resuspended in $200 \mu \mathrm{l}$ of storage buffer ( $40 \%$ glycerol, $50 \mathrm{mM}$ Tris- $\mathrm{HCl}$, $\mathrm{pH} 8.3,5 \mathrm{mM} \mathrm{MgCl} 2$ and $0.1 \mathrm{mM}$ EDTA). Transcription run-on assays were performed as described by Nevins (40), using $100 \mu \mathrm{l}$ of nuclei. Equivalent counts of nuclear RNA labeled with $\left[\alpha-{ }^{32} \mathrm{P}\right] \mathrm{UTP}$ $(3,000 \mathrm{Ci} / \mathrm{mmol})$ were hybridized for $36 \mathrm{~h}$ at $65^{\circ} \mathrm{C}$ to $5 \mu \mathrm{g}$ human (37) and mouse apo A-I cDNAs immobilized on Hybond-C Extra filters (Amersham Corp.). The empty vector plasmid was used as a negative control. After hybridization, filters were washed in $0.5 \times$ SSC and $0.1 \%$ SDS for $10 \mathrm{~min}$ at room temperature and twice for $30 \mathrm{~min}$ at $65^{\circ} \mathrm{C}$ an exposed to $\mathrm{x}$-ray film (X-OMAT-AR). Autoradiograms were analyzed by quantification scanning densitometry.

\section{Results}

Effect of fenofibrate on plasma apo A-I concentrations and lipoprotein composition. Human apo A-I (hA-I) transgenic and nontransgenic mice were treated for $7 \mathrm{~d}$ with fenofibrate $0.5 \%$ (wt/wt) mixed in mouse chow. In transgenic mice, treatment with fenofibrate resulted in a $760 \%$ increase in plasma human apo A-I concentrations (Table I). By contrast, in nontransgenic mice, plasma mouse apo A-I levels were decreased by $41 \%$ (Table I). In hA-I transgenic mice, endogenous plasma mouse apo A-I was undetectable, as previously described (31).

Gel filtration chromatography was performed to analyze the distribution of lipoproteins in plasma of transgenic and nontransgenic mice treated with fenofibrate. In hA-I transgenic mice, total plasma cholesterol levels were increased up to $260 \%$ of controls after fenofibrate treatment (Table II). This increase in plasma cholesterol concentration was due to an increase in HDL-cholesterol to $300 \%$ of control (Table II). More specifically, the cholesterol profile showed an increase of HDL particle size, whereas VLDL and LDL particles decreased to undetectable levels (Fig. 1). In nontransgenic mice, 
Table I. Influence of Fenofibrate on Plasma apo A-I Concentrations in Transgenic and Nontransgenic Mice

\begin{tabular}{|c|c|c|c|}
\hline \multirow[b]{2}{*}{ Treatment } & & hA-I & \multirow{2}{*}{$\frac{\mathrm{mA}-\mathrm{I}}{\text { Nontransgenic mice }}$} \\
\hline & & Transgenic mice & \\
\hline & & $m g / d l$ & $m g / d l$ \\
\hline \multirow[t]{2}{*}{ Control } & Before & $215 \pm 73$ & $100 \pm 19$ \\
\hline & After & $288 \pm 90$ & $118 \pm 22$ \\
\hline \multirow[t]{2}{*}{ Fenofibrate } & Before & $370 \pm 60$ & $103 \pm 13$ \\
\hline & After & $3,174 \pm 117 *$ & $61 \pm 7 *$ \\
\hline
\end{tabular}

Mice were treated $7 \mathrm{~d}$ with fenofibrate $0.5 \%$ (wt/wt) mixed in mouse chow. Plasma apo A-I concentrations were determined before the treatment and at the end of the experiments. Apo A-I levels are the mean \pm SD of five animals. $* P<0.01$ (ANOVA).

no significant changes in total cholesterol as well as in HDLcholesterol levels were observed after fenofibrate treatment (Table II) thereby confirming previous results (41).

To further characterize HDL particles formed in transgenic mice after fenofibrate treatment, proteins in the different eluted fractions were separated on a $4-20 \%$ SDS polyacrylamide gradient gel. Western blot analysis confirmed that human apo A-I was present in the HDL particle fractions (data not shown). This confirms that the increase in circulating apo A-I is associated with the appearance of large HDL particles.

Effect of fenofibrate on apo A-I gene expression in human apo A-I transgenic and nontransgenic mice. We next investigated whether the increase in plasma human apo A-I levels observed after fenofibrate treatment was due to an increase in liver apo A-I gene expression. In transgenic mice, treatment with fenofibrate resulted in a $97 \%$ increase in liver human apo A-I mRNA levels, whereas liver endogenous mouse apo A-I mRNA levels were reduced by $49 \%$ compared to untreated mice. In nontransgenic mice, a similar decrease in mouse apo A-I mRNA levels was obtained after fenofibrate administration (Fig. $2 A$ ). This opposite effect of fenofibrate on human and mouse apo A-I mRNA levels measured by dot blot hybridization was confirmed by Northern blot analysis (Fig. $2 B$ ). A comparable increase in liver weights was observed in all feno-

Table II. Plasma Total Cholesterol and HDL-cholesterol Levels in hA-I Transgenic and Nontransgenic Mice Treated for $7 d$ with Fenofibrate $(0.5 \% w t / w t)$

\begin{tabular}{lcc}
\hline \multicolumn{1}{c}{ Treatment } & Total cholesterol & HDL cholesterol \\
\hline & $m g / d l$ & $m g / d l$ \\
Transgenic mice & & \\
$\quad$ Before & $173 \pm 14$ & $149 \pm 12$ \\
After & $454 \pm 24^{*}$ & $450 \pm 20^{*}$ \\
Nontransgenic mice & & \\
$\quad$ Before & $84 \pm 5$ & $66 \pm 3$ \\
After & $92 \pm 11$ & $64 \pm 7$ \\
\end{tabular}

Plasma cholesterol concentrations were determined before the treatment and at the end of the experiments. Values are the mean \pm SD of five animals. $* P<0.05$ (ANOVA).

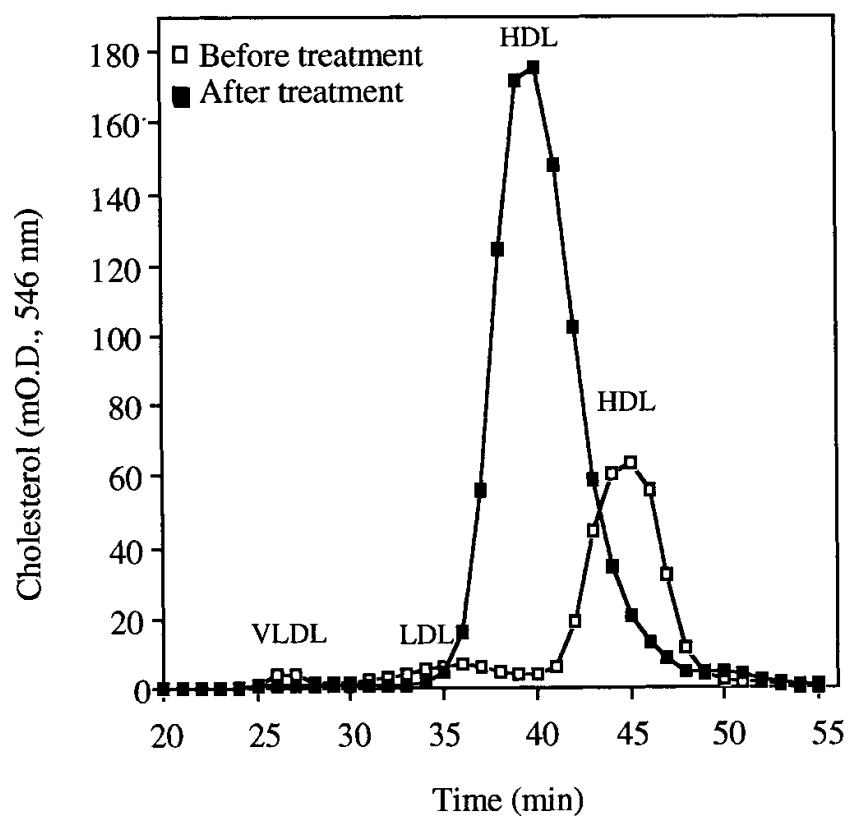

Figure 1. Distribution of cholesterol in plasma of transgenic mice before and after treatment with fenofibrate. Animals were treated for $7 \mathrm{~d}$ with fenofibrate $0.5 \%$. Plasma collected from mice before and after the treatment was analyzed by gel filtration chromatography as described in Methods. The eluted fractions were assessed for cholesterol concentrations.

fibrate treated mice reaching up to $160 \%$ of untreated control livers (data not shown), thus reflecting the peroxisome proliferator property of fibrates in rodents. Furthermore, mRNA levels of ACO, the rate-limiting enzyme in peroxisomal $\beta$-oxidation, whose induction by fibrates is strictly PPAR mediated (42), increased approximately sixfold both in transgenic and nontransgenic mice after fenofibrate administration (Fig. $2 \mathrm{~B}$ ).

To exclude the possibility that the effect of fenofibrate on human apo A-I gene expression is due to the site of transgene integration, we performed a complementary experiment using a transgenic mice line containing a $2.2-\mathrm{kb}$ human apo A-I genomic DNA fragment. In this transgenic mice line, human apo A-I gene is also expressed in the liver (30). After $7 \mathrm{~d}$ of treatment, human apo A-I mRNA levels were increased from $100 \pm 24$ in untreated mice to $237 \pm 3$ in fenofibrate-treated mice $(P<0.05)$. This increase in mRNA levels was associated with an increase in plasma human apo A-I concentrations reaching $1,360 \pm 630 \mathrm{mg} / \mathrm{dl}$ compared to $180 \pm 10 \mathrm{mg} / \mathrm{dl}$ in untreated mice $(P<0.05)$. These results thus strongly suggest that the induction of human apo A-I gene expression by fenofibrate is independent of the site of transgene integration and furthermore that the cis-element mediating the response to fenofibrate is present in the 2.2-kb genomic human apo A-I DNA fragment.

Dose- and time-dependent effects of fenofibrate. Fenofibrate treatment increased plasma human apo A-I concentration in a dose-dependent fashion, attaining maximal effects at a dose of $0.5 \%$ (Fig. $3 \mathrm{~A}$ ). At the lowest dose $(0.005 \%)$ of fenofibrate tested, plasma human apo A-I and HDL-cholesterol levels as well as liver apo A-I and ACO mRNA levels were not affected. At a dose of $0.05 \%$ of fenofibrate both plasma human apo A-I and HDL-cholesterol levels were in- 


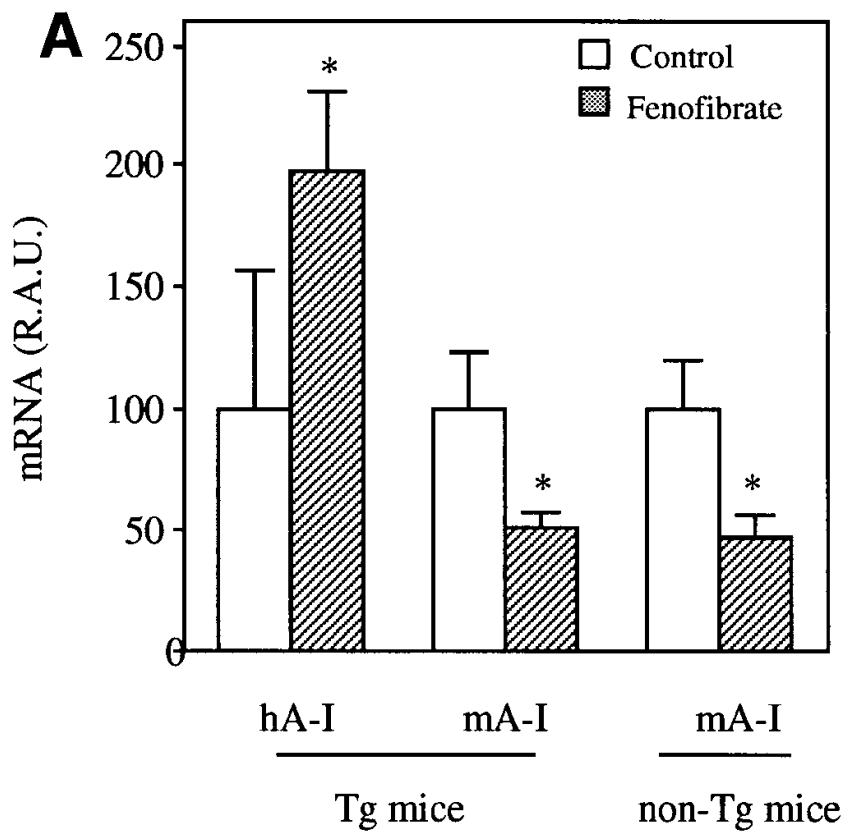

B
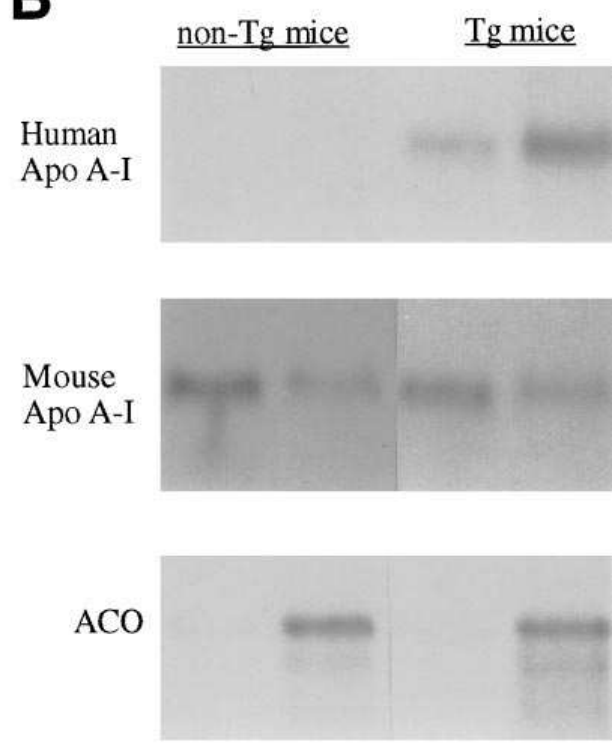

Fenofibrate

Figure 2. Effect of fenofibrate on liver apo A-I mRNA levels in human apo A-I transgenic $(T g)$ and control mice. Mice were treated for $7 \mathrm{~d}$ with fenofibrate $0.5 \%(\mathrm{wt} / \mathrm{wt})$ mixed in mouse chow. Total RNA was extracted from liver and human apo A-I $(h A-I)$ and mouse apo A-I $(m A-I)$ mRNA levels were measured after dot blot hybridization. (A) Bar graph shows hA-I and mA-I mRNA levels in control and fenofibrate-treated transgenic and nontransgenic mice. Values represent the mean \pm SD of five animals. Statistically significant differences from controls (ANOVA, $P<0.05$ ) are indicated by an asterisk. $(B)$ Northern blot analysis. $10 \mu \mathrm{g}$ of total mRNA was subjected to electrophoresis, transferred to a nylon membrane, and hybridized with different probes as described in Methods.

creased to 175 and $218 \%$ of controls, respectively (Fig. 3, $A$ and $B$ ). These increases were correlated with a $35 \%$ increase in hepatic human apo A-I mRNA levels (Fig. $3 C$ ). At this $0.05 \%$ dose a 2.5 -fold increase in ACO mRNA levels (Fig. $3 D$ ) and a small increase in liver weights could also be observed, thereby paralleling the dose-dependent effects of fenofibrate on apo A-I expression.

When mice were treated with fenofibrate $0.5 \%$ for different periods of time, plasma human apo A-I and HDL-cholesterol levels were increased (151 and $160 \%$ of controls, respectively) after $3 \mathrm{~d}$ of fenofibrate treatment (Fig. 4, $A$ and $B$ ). Human apo A-I and ACO mRNA levels were already increased (72 and $510 \%$, respectively) after $1 \mathrm{~d}$ of fenofibrate treatment (data not shown), indicating that the increase in plasma levels follows the increase in apo A-I gene expression.

Effect of fenofibrate on hepatic apo A-I gene transcription rates. To assess the effect of fenofibrate on apo A-I gene transcription rate, nuclear run-on transcription assays were performed on transgenic and nontransgenic mice, untreated (control) or treated for $5 \mathrm{~d}$ with fenofibrate $0.5 \%(\mathrm{wt} / \mathrm{wt})$. A $300 \%$ increase in human apo A-I gene transcription rate was observed in transgenic mice treated with fenofibrate, whereas the transcription rate of mouse apo A-I gene was decreased to 68 and $49 \%$ in transgenic and nontransgenic mice, respectively, in response to fenofibrate (Fig. 5).

Effect of gemfibrozil on apo A-I expression. Next we investigated whether the observed regulation of plasma apo A-I and hepatic apo A-I gene expression was a general property of all fibrates. Therefore, human apo A-I transgenic mice were treated for $7 \mathrm{~d}$ with gemfibrozil at $0.5 \%$, a dose found optimal for fenofibrate and previously shown to be active in rodents (24).

When mice were treated with gemfibrozil, plasma human apo A-I and HDL-cholesterol levels were increased by 32 and $73 \%$, respectively (Fig. 6, $A$ and $B$ ). The increase in HDL-cholesterol was accompanied by a shift to larger particles as observed with fenofibrate (data not shown). In addition, a $42 \%$ decrease in murine apo A-I mRNA levels was measured (Fig. $6 C$ ), whereas human apo A-I mRNA levels tended to increase. Thus, gemfibrozil seems to have an intermediate impact on apo A-I expression. This was also reflected by a less marked effect of gemfibrozil on ACO mRNA levels (Fig. 6D).

Fenofibric acid increases apo A-I gene expression in primary human hepatocytes. We previously reported that in rat, apo A-I gene expression was decreased due to a direct effect of fenofibric acid on hepatic cells (25). In view of the differential in vivo regulation of murine and human apo A-I in transgenic mice and to extend our observations in transgenic mice to the human situation, we decided to investigate whether the effect of fenofibric acid on human apo A-I gene expression could also be observed using primary cultures of adult human hepatocytes. Treatment of human hepatocytes for $72 \mathrm{~h}$ with fenofibric acid resulted in an $83 \%$ increase in secreted apo A-I only at the highest concentration of fenofibric acid $(500 \mu \mathrm{M})$ (Fig. $7 \mathrm{~A}$ ). This increase was associated with a $50 \%$ increase in apo A-I mRNA levels (Fig. 7 B). Secretion of apo A-II was also induced by fenofibric acid $100 \mu \mathrm{M}$, thereby confirming previous results (43). To assess the specificity of action of fenofibric acid, different hepatic proteins were measured in the supernatant of human hepatocytes. Transferrin secretion as well as mRNA levels remained constant upon treatment with fenofibric acid (Fig. 7, $A$ and $B$ ). As additional controls, the concentrations of albumin, haptoglobin, and ceruloplasmin were determined and were found to be unaffected by treatment with fenofibric acid (data not shown).

These results therefore demonstrate that, in contrast to rodent hepatocytes, fibrates increase human apo A-I gene ex- 

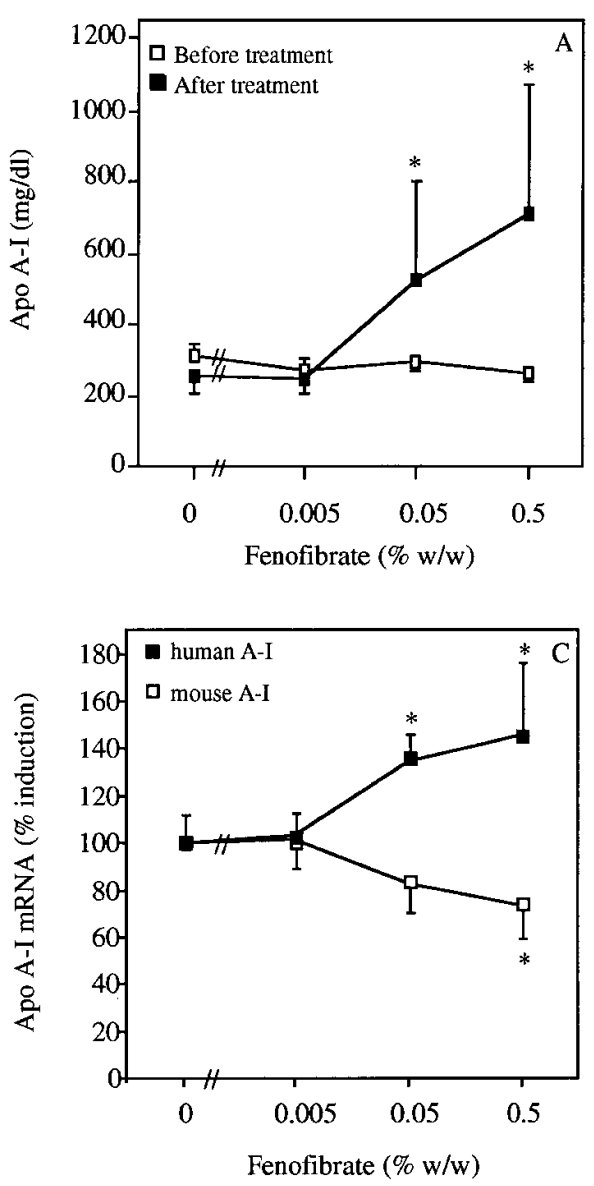
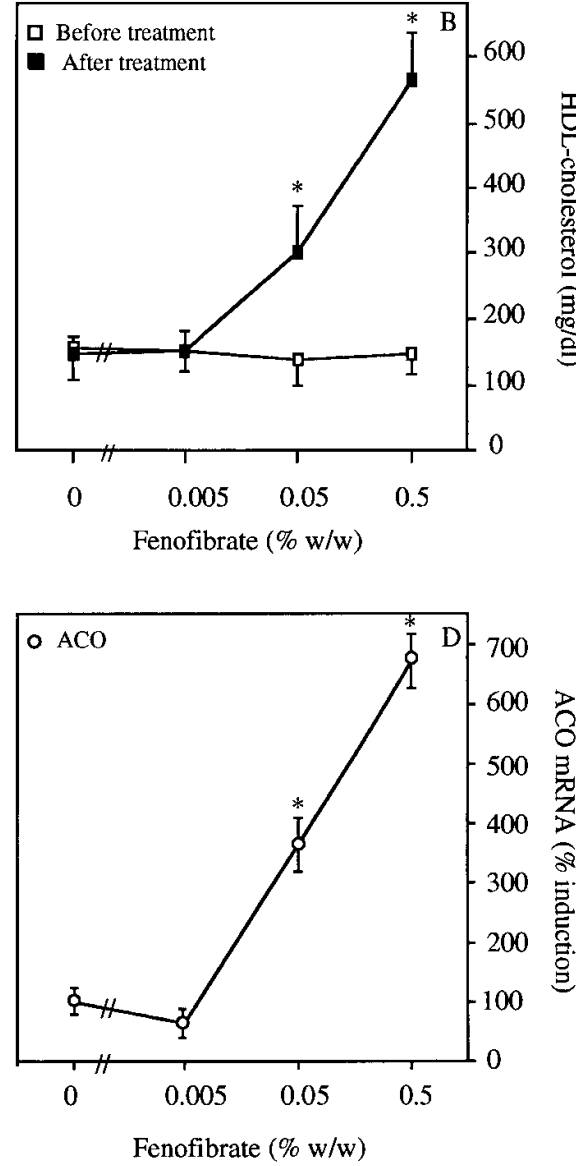

Figure 3. Dose-dependent effects of fenofibrate on plasma human apo A-I $(A)$ and HDL cholesterol levels $(B)$ and on liver human and mouse apo A-I $(C)$ and $\mathrm{ACO}(D)$ mRNA levels in hA-I transgenic mice. Animals were treated for $7 \mathrm{~d}$ with the indicated doses of fenofibrate. Plasma human apo A-I and HDL-cholesterol concentrations were measured before and after treatment as described in Methods. Each value represent the mean \pm SD of eight animals. Statistically significant differences from controls (ANOVA, $P<0.05$ ) are indicated by an asterisk. Liver RNA was extracted; human and mouse apo A-I and ACO mRNA levels were measured by dot blot analysis as described in Methods. Each value represents the mean \pm SD of five animals. pression in human hepatocytes, indicating that human liver also contains the necessary elements for apo A-I activation by fibrates.

\section{Discussion}

Transgenic models have been widely used to investigate the pro- or anti-atherogenic properties of human apolipoproteins (4, 44-47). Overexpression of human apo A-I not only protects the C57BL/6 susceptible strain of mice against early atherogenesis but is also sufficient to counteract the atherogenic properties of apo (a) (48) or the development of advanced ath- erosclerotic lesions in apo $\mathrm{E}$ knockout mice $(49,50)$. In view of these data, we can speculate that the modulation, i.e., up-regulation, of apo A-I gene expression could also exert a profound and beneficial impact on human atherosclerosis. The $5^{\prime}$ flanking region of the human apo A-I gene has been demonstrated to function as a liver transcriptional enhancer (51), and several trans-acting factors which are nuclear receptors have been shown to interact with the apo A-I gene promoter to modulate gene expression (52-58). However, since most reports are based on in vitro methods, we decided to take advantage of the human apo A-I transgenic mice to investigate the regulation of human apo A-I gene expression in an in vivo context. It has

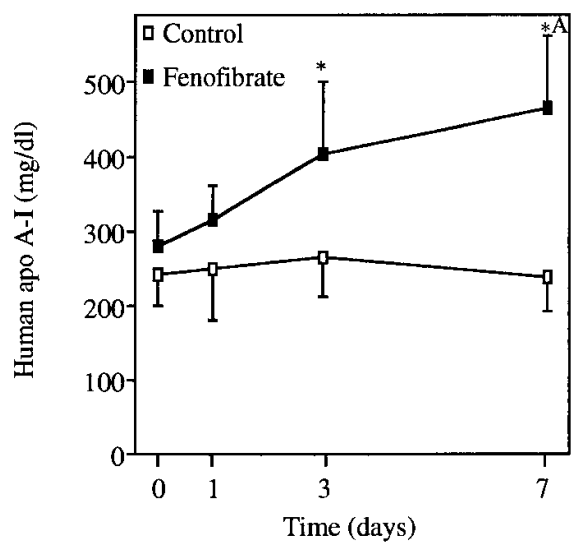

Figure 4. Time-dependent effects of fenofibrate on plasma human apo A-I and HDL cholesterol levels in hA-I transgenic mice. Mice were treated with fenofibrate $0.5 \%$ for the indicated periods of time. Before and at the end of the treatment, blood was taken and human apo A-I $(A)$ as well as HDL cholesterol levels $(B)$ were measured as described in Methods. Each value represents the mean \pm SD of 10 animals. Statistically significant differences from controls (ANOVA, $P<0.005$ ) are indicated by an asterisk. 


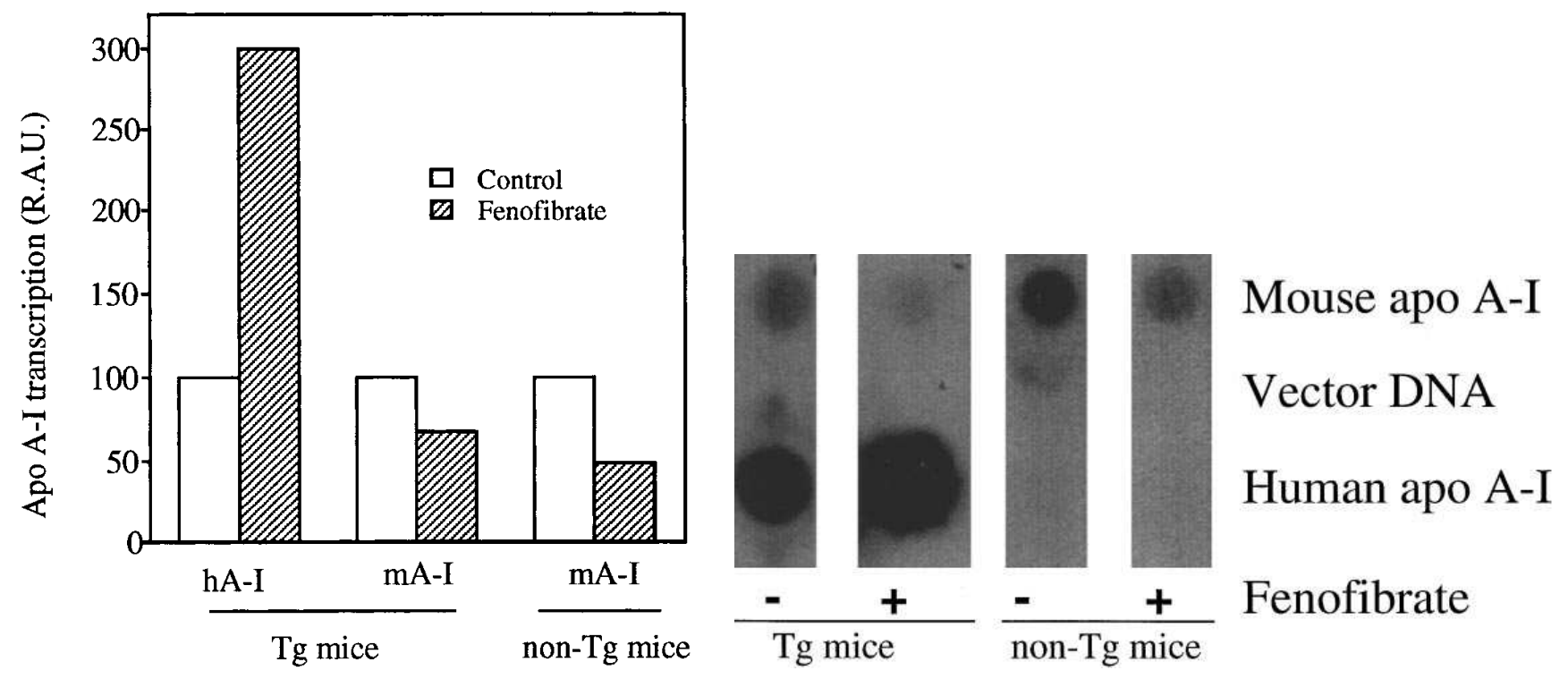

Figure 5. Effect of fenofibrate on hepatic apo A-I gene transcription rate. Nuclear run-on assays were performed on transgenic and nontransgenic mice treated for $5 \mathrm{~d}$ with fenofibrate $0.5 \%(\mathrm{wt} / \mathrm{wt})$ mixed in mouse chow and compared to untreated (control) mice.

been previously demonstrated that high fat diet increases HDL particle concentrations and apo A-I transport rates in hA-I transgenic mice (59). Another study using hA-I transgenic mice to examine the effect of probucol on lipid parameters showed a decrease in HDL-cholesterol concentrations and apo A-I transport rate (60).

In rats, fenofibrate induces a decrease in HDL-cholesterol concentrations (8) as well as in apo A-I mRNA levels (24).
The down-regulation of apo A-I gene expression reported in rat is reproduced in our murine model since liver endogenous apo A-I mRNA levels are decreased in transgenic and nontransgenic mice treated with fenofibrate. In humans, however, treatment with fenofibrate increases plasma HDL-cholesterol and apo A-I levels $(6,26,27)$, but the molecular mechanisms of this induction remains unclear. The results from this study show that fibrates increase plasma HDL and human apo A-I
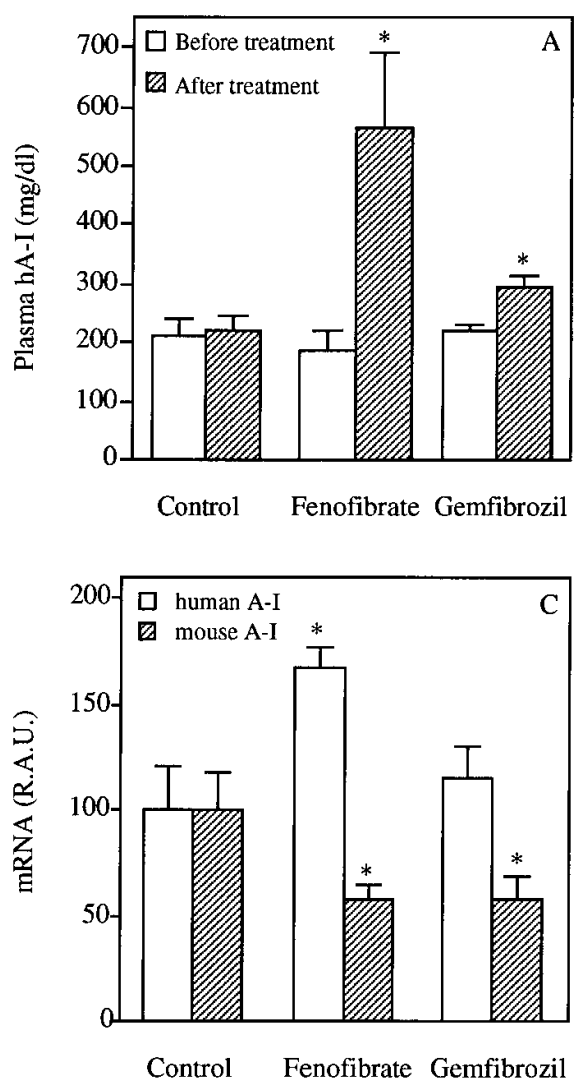
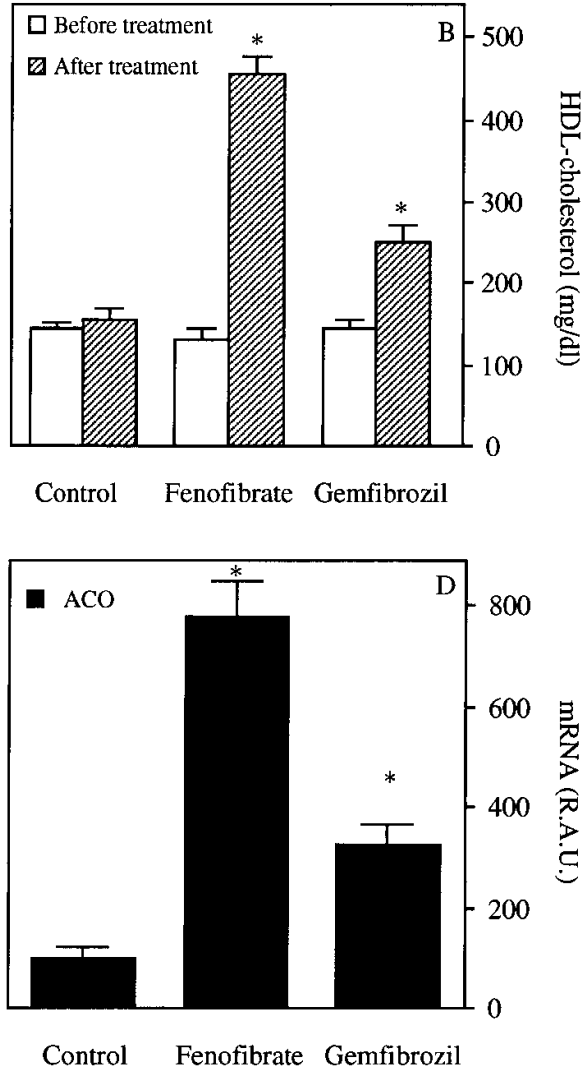

Figure 6. Comparison of the effects of gemfibrozil and fenofibrate on plasma apo A-I $(A)$ and HDL-cholesterol $(B)$ levels and on liver apo A-I $(C)$ and $\mathrm{ACO}(D)$ mRNA levels in hA-I transgenic mice. Animals were treated with $0.5 \%$ of fenofibrate or gemfibrozil for $7 \mathrm{~d}$. Plasma human apo A-I and HDL-cholesterol concentrations were measured before and after the treatment period. Each value represents the mean \pm SD of five animals. Human and mouse apo A-I and ACO mRNA levels were measured by dot blot analysis as described in Methods. Statistically significant differences from controls (ANOVA, $P<0.05$ ) are indicated by an asterisk. 
B

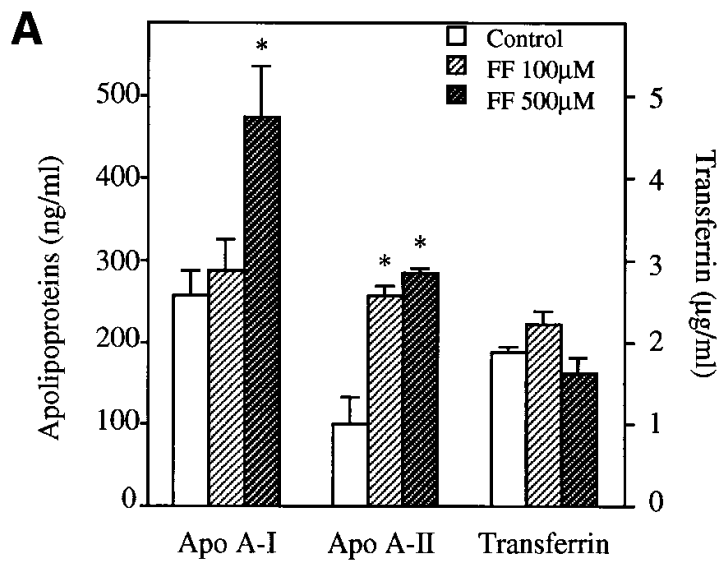

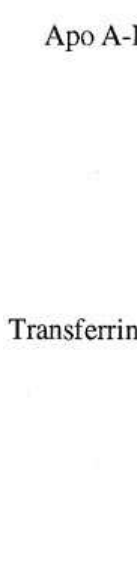
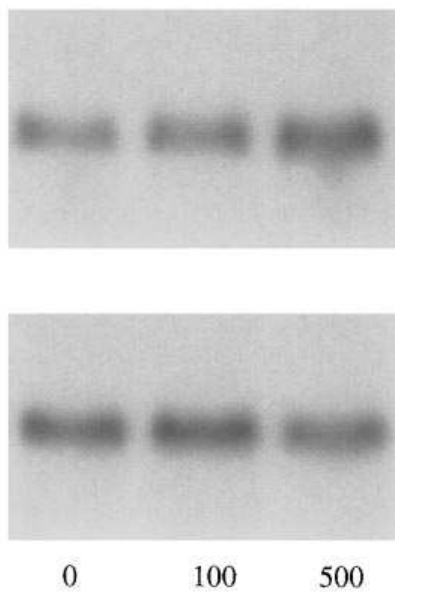

Fenofibric acid $(\mu \mathrm{M})$
Figure 7. Effect of fenofibric acid on apo A-I, apo A-II, and transferrin secretion $(A)$ and mRNA levels $(B)$ in primary cultures of adult human hepatocytes. Human hepatocytes were isolated and treated with fenofibric acid 100 or $500 \mu \mathrm{M}$ or vehicle (control; DMSO) for $72 \mathrm{~h}$ as described in Methods. (A) Bar graph shows human apo A-I, A-II, and transferrin secreted in the culture medium. After a 72-h treatment period, the concentration of different proteins was measured by ELISA as described in Methods. Data are mean \pm SD of three replicates. Statistically significant differ-

ences from controls (ANOVA, $P<0.01$ ) are indicated by an asterisk. $(B)$ Northern blot analysis. Total cellular RNA was extracted, and $10 \mu g$ of total RNA was subjected to electrophoresis, transferred to a nylon membrane, and hybridized with the indicated probes as described in Methods.

concentrations as well as liver human apo A-I mRNA levels in transgenic mice. This increase in human apo A-I mRNA level is due to an increase in the transcription rate as demonstrated by run-on transcription assays. In addition, experiments on a second transgenic mice line demonstrate that the effect of fenofibrate on human apo A-I gene expression is not due to the site of transgene integration, but requires a cis-element present in the 2.2-kb fragment, which extends from $256 \mathrm{bp} 5^{\prime}$ to $80 \mathrm{bp} 3^{\prime}$ of the human apo A-I gene and contains the liverspecific enhancer (30). Furthermore, experiments on isolated human hepatocytes, showing an increase in apo A-I secretion and apo A-I mRNA levels, support the hypothesis that the increase in circulating apo A-I observed in fenofibrate-treated patients results, at least partially, from a direct effect on liver apo A-I gene expression. A previous report demonstrated that fenofibrate also increases apo A-I synthesis in the human HepG2 hepatoma cell line (61). In humans, a modest but significant increase in plasma apo A-I levels after fenofibrate treatment has been reported $(6,27)$. Interestingly, our study shows that human apo A-I response to fibrates is amplified in hA-I transgenic mice. The dramatic increase in plasma apo A-I may be a consequence of the high basal expression due to the presence of a high number of human apo A-I gene copies in the transgenic mice. Indeed, apo A-I concentration in human plasma is $\sim 100 \mathrm{mg} / \mathrm{dl}$, whereas human plasma apo A-I levels in transgenic mice are ranging from 200 to $400 \mathrm{mg} / \mathrm{dl}$. Alternatively, it cannot be excluded that fibrates, in addition to their effects on apo A-I gene transcription, exert posttranscriptional effects on plasma HDL and apo A-I metabolism and may affect the rates of catabolism of human apo A-I-containing HDL particles.

Despite the opposite regulation of murine and human apo A-I gene expression after fenofibrate treatment, an increase in liver weight is observed in both hA-I transgenic and control mice. Moreover, the induction of human apo A-I gene expression was accompanied by a strong dose-dependent induction of ACO gene expression, the rate-limiting enzyme in the pathway of the peroxisomal $\beta$-oxidation of fatty acids. Fibrates activate specific receptors, called PPARs, which interact with specific response elements, termed peroxisome proliferator response elements (PPREs), in the regulatory sequences of target genes, such as ACO $(20,62)$. A functional PPRE, which is transactivated by PPAR $\alpha$ in transient cotransfection assays, has been identified in the A-site of the liver-specific enhancer in the apo A-I gene promoter (52). Our study performed in transgenic animals containing, in addition to the endogenous mouse apo A-I gene, an 11- or a 2.2-kb human apo A-I genomic DNA fragment, suggests that the opposite effects of fibrates on human and rodent apo A-I gene transcription are mediated through distinct elements present in cis. Furthermore, the experiments performed in human hepatocytes demonstrate that human liver, as well as mouse liver, contains the necessary trans-factors to mediate the induction of apo A-I expression by fibrates.

This up-regulation of human apo A-I gene expression after fenofibrate treatment, which occurs at the transcriptional level as demonstrated by run-on transcription assays, may be, at least partially, PPAR mediated. Conversely, the down-regulation of rodent apo A-I gene expression after fibrate treatment could be explained by the presence of a nonfunctional PPRE in the rodent apo A-I gene promoter, since it has been demonstrated that, compared to the human A-site, the rat apo A-I A-site contains three base-pair changes which prevent PPAR $\alpha / R X R \alpha$ binding (63). In absence of a functional PPRE, fibrates may decrease rodent apo A-I transcription by downregulating the expression of the positive hepatic transcription factor HNF-4 (64). Alternatively, rodent apo A-I gene transcription may be decreased after fibrates by a mechanism involving negative fibrate regulatory elements located in the basal apo A-I gene promoter (52).

Another fibrate, gemfibrozil, was also efficient in increasing human apo A-I plasma concentrations in transgenic mice, but to an intermediate level compared to fenofibrate. Furthermore, quantitatively distinct effects between gemfibrozil and fenofibrate were observed on human apo A-I as well as ACO mRNA levels in liver. The less pronounced effect of gemfibrozil on ACO mRNA levels was also observed in rats (7). Human apo A-I gene regulation in response to different fi- 
brates probably results from a subtle balance between their effects on the negative regulatory elements in the basal gene promoter and the PPAR-dependent positive regulation of apo A-I gene expression (52).

In addition to their effects on apo A-I gene transcription, different fibrates may elicit different metabolic responses. Indeed, both in rodents $(65,66)$ as well as in humans $(28,29)$, gemfibrozil has been shown to be a more potent HDL inducer than the other clinically used fibrates. Gemfibrozil, unlike other fibrates, has also been shown to increase plasma apo $\mathrm{E}$ concentrations $(24,66)$. Fibrates and other peroxisome proliferators clearly exhibit a wide array of biological activities and potential side-effects both in rodents and in humans (67). In particular, the impact of fibrates on HDL metabolism is obviously not restricted to apo A-I, since several clinical studies evidenced an increase in plasma apo A-II concentrations in fenofibrate-treated patients $(6,27,43)$. This induction is due to a fenofibrate-mediated increase of human apo A-II gene transcription in HepG2 cells as well as in primary human hepatocytes, which is mediated by the interaction of PPAR with a PPRE located in the J site of the apo A-II promoter (43). Since Lp A-I are considered to be better protectors against atherosclerosis than Lp A-I/A-II (1), the increase in apo A-II expression might be considered to be an adverse property of fibrates (67).

Taken together, our data indicate that transgenic mice provide a unique and powerful means to investigate in vivo gene regulation of human apolipoproteins. The transgenic model can be used not only to extend the in vitro characterization of apolipoprotein gene promoters, but also to dissect the mechanisms underlying the antiatherogenic properties of hypolipidemic drugs. Since we recently produced transgenic rabbits expressing human apo A-I in the liver (68), the consequences of apo A-I induction by fibrates on the development of atherosclerosis could be further studied in this rabbit model, which is more relevant for human atherosclerosis. Finally, other transgenic models, such as mice expressing the human apo A-I and apo A-II genes under the control of their respective promoters, could be generated to delineate the pharmacological properties of drugs, such as fibrates, on different human apolipoproteins in one single animal model.

\section{Acknowledgments}

We thank F. Attenot, I. Viry, and S. Alvarez for excellent technical assistance. We also thank F. Bouhet and P. Feydel for technical support, C. Fievet and A. Tailleux for mouse apo A-I determination, and D. Parrot for providing fenofibric acid.

This work was supported by the BIOAVENIR program financed by Rhône Poulenc, Ministère de l'Industrie et du Commerce Extérieur. J. Auwerx is a Directeur de Recherche, and B. Staels a Chargé de Recherche of the Centre National de la Recherche Scientifique.

\section{References}

1. Puchois, P., A. Kandoussi, J.L. Fourrier, M. Bertrand, E. Koren, and J.C. Fruchart. 1987. Apolipoprotein A-I containing lipoproteins in coronary heart disease. Atherosclerosis. 68:35-40.

2. Fruchart, J.C., G. Ailhaud, and J.M. Bard. 1993. Heterogeneity of high density lipoprotein particles. Circulation. 87:22-27.

3. Forte, T.M., and M.R. McCall. 1994. The role of apolipoprotein A-I-containing lipoproteins in atherosclerosis. Curr. Opin. Lipidol. 5:354-364.

4. Rubin, E.M., R.M. Krauss, E.A. Spangler, J.G. Verstuyft, and S.M. Clift. 1991. Inhibition of early atherogenesis in transgenic mice by human apolipoprotein AI. Nature (Lond.). 353:265-267.

5. Sirtori, C.R., and G. Franceschini. 1988. Effects of fibrates on serum lip- ids and atherosclerosis. Pharmacol. Ther. 37:167-191.

6. Balfour, J.A., D. McTavish, and R.C. Heel. 1990. Fenofibrate, a review of its pharmacodynamic and pharmacokinetic properties and therapeutic use in dyslipidemia. Drugs. 40:260-290.

7. Staels, B., N. Vu-Dac, V.A. Kosykh, R. Saladin, J.C. Fruchart, J. Dallongeville, and J. Auwerx. 1995. Fibrates downregulate apolipoprotein C-III expression independent of induction of peroxisomal acyl coenzyme A oxidase. $J$. Clin. Invest. 95:705-712.

8. Petit, D., M.T. Bonnefis, C. Rey, and R. Infante. 1988. Effects of ciprofibrate and fenofibrate on liver lipids and lipoprotein synthesis in normo- and hypercholesterolemic rats. Atherosclerosis. 74:215-225.

9. Goldberg, A.P., D.M. Applebaum-Bowden, E.L. Bierman, W.R Hazzard, L.B. Haas, D.J. Sherrard, J.D. Brunzell, J.K. Huttunen, C. Ehnholm, and E.A. Nikkilä. 1979. Increase in lipoprotein lipase during clofibrate treatment of hypertriglyceridemia in patients on hemodialysis. N. Engl. J. Med. 301:1073-1076.

10. Staels, B., and J. Auwerx. 1992. Perturbation of developmental gene expression in rat liver by fibric acid derivatives: lipoprotein lipase and $\alpha$-fetoprotein as models. Development. 115:1035-1043.

11. Lock, E.A., A.M. Michell, and C.R. Elcombe. 1989. Biochemical mechanisms of induction of hepatic peroxisome proliferation. Annu. Rev. Pharmacol. Toxicol. 29:145-163.

12. Blaauboer, B.J., C.W.M. van Holstein, R. Bleumink, W.C. Mennes, F.N.A.M. van Pelt, S.H. Yap, J.F. van Pelt, A.A.J. van Iersel, A. Timmerman, and B.P. Schmid. 1990. The effect of beclobric acid and clofibric acid on peroxisomal $\beta$-oxidation and peroxisome proliferation in primary cultures rat, monkey and human hepatocytes. Biochem. Pharmacol. 40:521-528.

13. Reddy, J.K., S.K. Goel, M.R. Nemali, J.J. Carrino, T.G. Laffler, M.K Reddy, S.J. Sperbeck, T. Osumi, T. Hashimoto, N.D. Lalwani, and M.S. Rao 1986. Transcriptional regulation of peroxisomal fatty acyl-CoA oxidase and enoyl-CoA hydratase/3-hydroxy-acyl-CoA dehydrogenase in rat liver by peroxisome proliferators. Proc. Natl. Acad. Sci. USA. 83:1747-1751.

14. Lazarow, P., and C. de Duve. 1976. A fatty acyl-CoA oxidizing system in rat liver peroxisomes: enhancement by clofibrate, a hypolipidemic drug. Proc. Natl. Acad. Sci. USA. 73:2042-2046.

15. Kozuka, H., J. Yamada, S. Horie, T. Watanabe, T. Suga, and T. Ikeda. 1991. Characteristics of induction of peroxisomal fatty acid oxidation-related enzymes in rat liver by drugs. Biochem. Pharmacol. 41:617-623.

16. Milton, M.N., C.R. Elcombe, and G.G. Gibson. 1990. On the mechanism of induction of microsomal cytochrome P450IVA1 and peroxisome proliferation in rat liver by clofibrate. Biochem. Pharmacol. 40:2727-2732.

17. Tomaszewski, K.E., S.W. Heindel, W.L. Jenkins, and R.L. Melnick. 1990. Induction of peroxisomal acyl CoA oxidase activity and lipid peroxidation in primary rat hepatocyte cultures. Toxicology. 65:49-60.

18. Reddy, J.K., D.L. Azarnoff, and C.E. Hignite. 1980. Hypolipidaemic hepatic peroxisome proliferators from a new class of chemical carcinogens. Nature (Lond.). 283:397-398.

19. Isseman, I., and S. Green. 1990. Activation of a member of the steroid hormone receptor superfamily by peroxisome proliferators. Nature (Lond.). 347:645-650.

20. Tugwood, J.D., I. Issemann, R.G. Anderson, K.R Bundell, W.L. McPheat, and S. Green. 1992. The mouse peroxisome proliferator activated receptor recognizes a response element in the $5^{\prime}$ flanking sequence of the rat acyl CoA oxidase gene. EMBO. (Eur. Mol. Biol. Organ.) J. 11:433-439.

21. Dreyer, C., G. Krey, H. Keller, F. Givel, G. Helftenbein, and W. Wahli. 1992. Control of the peroxisomal $\beta$-oxidation pathway by a novel family of nuclear hormone receptors. Cell. 68:879-887.

22. Auwerx, J. 1992. Regulation of gene expression by fatty acids and fibric acid derivatives: an integrative role for peroxisome proliferator activated receptors. Horm. Res. 38:269-277.

23. Keller, H., C. Dreyer, J. Medin, A. Mahfoudi, K. Ozato, and W. Wahli. 1993. Fatty acids and retinoids control lipid metabolism through activation of peroxisome proliferator-activated receptor-retinoid X receptor heterodimers. Proc. Natl. Acad. Sci. USA. 90:2160-2164.

24. Staels, B., A. van Tol, T. Andreu, and J. Auwerx. 1992. Fibrates influence the expression of genes involved in lipoprotein metabolism in a tissueselective manner in the rat. Arterioscler. Thromb. 12:286-294.

25. Berthou, L., R. Saladin, D. Branellec, P. Calder, J.C. Fruchart, P. Denefle, J. Auwerx, and B. Staels. 1995. Regulation of rat liver apolipoprotein A-I and A-II gene expression by fibrates and dietary fatty acids. Eur. J. Biochem. 232:179-187.

26. Malmendier, C.L., and C. Delecroix. 1985. Effects of fenofibrate on high and low density lipoprotein metabolism in heterozygous familial hypercholesterolemia. Atherosclerosis. 55:161-169.

27. Bard, J.M., H.J. Parra, R. Camare, G. Luc, O. Ziegler, C. Dachet, E. Brueckert, P. Douste-Blazy, P. Drouin, B. Jacotot, J.L. De Gennes, U. Keller, and J.C. Fruchart. 1992. A multicenter comparison of the effects of simvastatin and fenofibrate therapy in severe primary hypercholesterolemia, with particular emphasis on lipoproteins defined by their apolipoprotein composition. $\mathrm{Me}$ tabolism. 41:498-503.

28. Manninen, V. 1983. Clinical results with gemfibrozil and background to the Helsinki Heart Study. Am. J. Cardiol. 52:35B-38B.

29. Gnasso, A., B. Lehner, W. Haberbosch, O. Leiss, K. von Bergmann, and 
J. Augustin. 1986. Effect of gemfibrozil on lipids, apoproteins, and postheparin lipolytic activities in normolipidemic subjects. Metabolism. 35:387-393.

30. Walsh, A., Y. Ito, and J.L. Breslow. 1989. High levels of human apolipoprotein A-I in transgenic mice result in increased plasma levels of small high density lipoprotein (HDL) particles comparable of human $\mathrm{HDL}_{3}$. J. Biol. Chem. 264:6488-6494.

31. Rubin, E.D., B.Y. Ishida, S.M. Clift, and R.M. Krauss. 1991. Expression of human apolipoprotein A-I in transgenic mice results in reduced plasma levels of murine apolipoprotein A-I and the appearance of two new high density lipoprotein size subclasses. Proc. Natl. Acad Sci. USA. 88:434-438.

32. Gugen-Guillouzo, C., and A. Guillouzo. 1986. Methods for preparation of adult and fetal hepatocytes. In Isolated and Cultured Hepatocytes (Les edition INSERM and John Libbey, Euro text.) A. Guillouzo and C. Gugen-Guillouzo, editors. Les Editions ISERM and John Libbey Euro Text. Paris. 1-12.

33. Fruchart J.C., C. Fievet, and P. Puchois. 1985. Apolipoproteins. In Methods of Enzymatic Analysis. H.U. Bergmeyer, editor. Academic Press, New York. 3:126-138.

34. Voller, A., D.E. Bidwell, and A. Bartlett. 1976. Enzyme immunoassays in diagnostic medicine. Theory and practice. Bull. W. H. O. 53:55-65.

35. Chomczynski, P., and N. Sacchi. 1987. Single step method for RNA isolation by acid guanidinium-thiocyanate-phenol-chloroform extraction. Anal. Biochem. 162:156-159.

36. Staels, B., J. Auwerx, L. Chan, A. van Tol, M. Rosseneu, and G. Verhoeven. 1989. Influence of development, oestrogens and food intake on apolipoprotein A-I, A-II and E mRNA in the rat liver and intestine. J. Lipid. Res. 30:1137-1145.

37. Breslow, J.L., D. Ross, J. McPherson, H. Williams, A.L. Nussbaum, S.K. Karathanasis, and V.I. Zannis. 1982. Isolation and characterization of cDNA clones for human apolipoprotein A-I. Proc. Natl. Acad. Sci. USA. 79:6861-6865.

38. Osumi, T., H. Ozasa, and T. Hashimoto. 1984. Molecular cloning of cDNA for rat acyl-CoA oxidase. J. Biol. Chem. 259:2031-2034.

39. Uzan, G., M. Frain, I. Park, C. Besmond, G. Maessen, J.S. Trepat, M. Zakin, and A. Kahn. 1984. Molecular cloning and sequence analysis of cDNA for human transferrin. Biochem. Biophys. Res. Commun. 119:273-281.

40. Nevins, J.R. 1987. Isolation and analysis of nuclear RNA. Methods Enzymol. 152:234-241.

41. Olivier, P., M.O. Plancke, D. Marzin, V. Clavey, J. Sauzieres, and J.C. Fruchart. 1988. Effects of fenofibrate, gemfibrozil and nicotinic acid on plasma lipoprotein levels in normal and hyperlipidemic mice. Atherosclerosis. 70:107-114.

42. Lee, S.T., T. Pineau, J. Drago, E.J. Lee, J.W. Owens, D.L. Kroetz, P.M. Fernandez-Salguero, H. Westphal, and K.J. Gonzalez. 1995. Targeted disruption of the $\alpha$ isoform of the peroxisome proliferator-activated receptor gene in mice results in abolishment of the pleiotropic effects of peroxisome proliferators. Mol. Cell. Biol. 15:3012-3022.

43. Vu-Dac, N., K. Schoonjans, V. Kosykh, J. Dallongeville, J.C. Fruchart, B. Staels, and J. Auwerx. 1995. Fibrates increase human apolipoprotein A-II expression through activation of peroxisome proliferator-activated receptor. $J$. Clin. Invest. 96:741-750.

44. Schultz, J.R., J.G. Verstuyft, E.L. Gong, A.V. Nichols, and E.M. Rubin. 1993. Protein composition determines the anti-atherogenic properties of HDL in transgenic mice. Nature (Lond.). 365:762-764.

45. Stoltzfus, L., and E.M. Rubin. 1993. Atherosclerosis. Insights from the study of transgenic and gene-targeted mice. Trends Cardiovasc. Med. 3:130-134.

46. Breslow, J.L. 1993. Transgenic mouse models of lipoprotein metabolism and atherosclerosis. Proc. Natl. Acad. Sci. USA. 90:8314-8318.

47. Breslow, J.L. 1994. Lipoprotein metabolism and atherosclerosis susceptibility in transgenic mice. Curr. Opin. Lipidol. 5:175-184.

48. Liu, A.C., R.M. Lawn, J.G. Verstuyft, and E.M. Rubin. 1994. Human apolipoprotein A-I prevents atherosclerosis associated with apolipoprotein (a) in transgenic mice. J. Lipid. Res. 35:2263-2267.

49. Paszty, C., N. Maeda, J. Verstuyft, and E.M. Rubin 1994. Apolipoprotein AI transgene corrects apolipoprotein E deficiency-induced atherosclerosis in mice. J. Clin. Invest. 94:899-903.
50. Plump, A.S., C.J. Scott, and J.L. Breslow. 1994. Human apolipoprotein A-I gene expression increase high density lipoprotein and suppresses atherosclerosis in the apolipoprotein E-deficient mouse. Proc. Natl. Acad. Sci. USA. 91:9607-9611.

51. Widom, R.L., J.A.A. Ladias, S. Kouidou, and S.K. Karathanasis. 1991 Synergistic interactions between transcription factors control expression of the apolipoprotein AI gene in liver cells. Mol. Cell. Biol. 11:677-687.

52. Vu-Dac, N., K. Schoonjans, B. Laine, J.C. Fruchart, J. Auwerx, and B. Staels. 1994. Negative regulation of the human apolipoprotein AI promoter by fibrates can be attenuated by the interaction of the peroxisome-proliferatoractivated receptor with its response element. J. Biol. Chem. 269:31012-31018.

53. Papazafiri, P., K. Ogami, D.P. Ramji, A. Nicosia, P. Monaci, C. Cladaras, and V.I. Zannis. 1991. Promoter elements and factors involved in hepatic transcription of the human apo A-I gene positive and negative regulators bind to overlapping site. J. Biol. Chem. 5790-5797.

54. Harnish, D., S. Malik, and S.K. Karathanasis. 1994. Activation of apolipoprotein A-I gene transcription by the liver-enriched factor HNF-3. J. Biol. Chem. 269:28220-28226.

55. Chan, J., H. Nakabayashi, and N.C.W. Wong. 1993. HNF-4 increases activity of the rat apo A-I gene. Nucleic Acids Res. 21:1205-1211.

56. Rottman, J.N., R.L. Widom, B. Nadal-Ginard, V. Mahdavi, and S.K. Karathanasis. 1991. A retinoic acid-responsive element in the apolipoprotein AI gene distinguishes between two different retinoic acid response pathways. Mol. Cell. Biol. 11:3814-3820.

57. Ladias, J.A.A., and S.K. Karathanasis. 1991. Regulation of the apolipoprotein AI gene by ARP-1, a novel member of the steroid receptor superfamily. Science (Wash. DC). 251:561-565.

58. Ge, R., M. Rhee, S. Malik, and S.K. Karathanasis. 1994. Transcriptional repression of apolipoprotein AI gene expression by orphan receptor ARP-1. J. Biol. Chem. 269:13185-13192.

59. Hayek, T., Y. Ito, N. Azrolan, R.B. Verdery, K. Aalto-Setälä, A. Walsh, and J.L. Breslow. 1993. Dietary fat increases high density lipoprotein (HDL) levels both by increasing the transport rates and decreasing the fractional catabolic rates of HDL cholesterol ester and apolipoprotein (apo) A-I. J. Clin. Invest. 91:1665-1671.

60. Hayek, T., T. Chajek-Shaul, A. Walsh, N. Azrolan, and J.L. Breslow. 1991. Probucol decreases apolipoprotein A-I transport rate and increases high density lipoprotein cholesteryl ester fractional catabolic rate in control and human apolipoprotein A-I transgenic mice. Arterioscler. Thromb. 11:1295-1302.

61. Hahn, S.E., and D.M. Goldberg. 1992. Modulation of lipoprotein production in HepG2 cells by fenofibrate and clofibrate. Biochem. Pharmacol. 43: $625-633$.

62. Osumi, T., J.K. Wen, and T. Hashimoto. 1991. Two cis-acting regulatory elements in the peroxisome proliferator-responsive element enhancer region of rat acyl-CoA oxidase gene. Biochem. Biophys. Res. Commun. 175:866-871.

63. Klausing, K., R. Straney, and M. Briggs. 1995. The human apolipoprotein A1 promoter contains a novel PPRE. Circulation. 92:I-291. (Abstr.)

64. Hertz, R., J. Bishara-Shieban, and J. Bar-Tana. 1995. Mode of action of peroxisome proliferators as hypolipidemic drugs. Suppression of apolipoprotein C-III. J. Biol. Chem. 270:13470-13475.

65. Krause, B.R., and R.S Newton. 1985. Apolipoprotein changes associated with the plasma lipid-regulating activity of gemfibrozil in cholesterol-fed rats. J. Lipid. Res. 26:940-949.

66. Krause, B.R., and R.S Newton. 1986 Gemfibrozil increases both apo A-I and apo E concentrations. Comparison to other lipids regulators in cholesterolfed rats. Atherosclerosis. 59:95-98.

67. Gould, A.L., J.E. Rossouw, N.C. Santanello, J.F. Heyse, and C.D. Furberg. 1995. Cholesterol reduction yields clinical benefit. A new look at old data. Circulation. 61:2274-2282.

68. Duverger, N., F. Emmanuel, C. Viglietta, A. Tailleux, P. Benoit, F. Attenot, S. Cuiné, C. Fievet, B. Laine, et al. 1994. Human apolipoprotein A-I gene transfer in the rabbit: incidence on atherogenesis. Circulation. 90:I-240. (Abstr.) 